\title{
Financial Feasibility Study of the Construction of New High School Building (Case Study of XYZ Foundation)
}

\author{
Zafirah Maria Ulfa and Ahmad Danu Prasetyo
}

\begin{abstract}
XYZ Foundation manages several unit of different education levels as part of private education sector. At the time being, the Foundation sees a necessity to encourage the development of one of its units, namely the high school unit. Continuous curriculum development and the addition of classes and facilities require more space to be realized so the school can admit more student, as the interest of prospective students continues to increase every year.

But the current school building cannot accommodate any more development. The current high school unit area is still integrated with the junior school unit area. This happen because the junior school unit was built first by the Foundation and later the high school unit. And because of that, the junior school unit occupy most of the area dan already has a better and more comprehensive facilities than the high school.

So, the foundation decided to construct a new building for high school unit in separate area. And it is expected that in the school year of 2021 the new buildings are ready to welcome the students. This financial feasibility study is conducted to assess whether the project is feasible or not. The parameters used to assess the project are Net Present Value (NPV), Internal Rate Return (IRR), Payback Period (PBP), Profitability Index (PI) and risk analysis is also conducted.
\end{abstract}

Index Terms - Financial Feasibility Study, NPV, IRR, PBP, PI, School Building.

\section{INTRODUCTION}

In Indonesia, the people are required to attend compulsory basic education for nine years, six years in elementary school and three years in junior high school. And since 2015, the government has also sought to extend the compulsory education program to twelve years. This is none other but a real effort of the government to improve the quality of human resources in order to compete globally. Because according to research conducted by Nowak [6], it supports the view that education also contributes to a country's economic growth.

Therefore, the government wants to fund the institutions needed to meet this increasing demand, but they often do not have enough money, and as a result the private sector responds. Not only present as assistance to meet increasing demand, schools managed by private sector are also become an alternative choice for the people. Likewise, in Indonesia data shows that in the school year of 2018/2019 the role of private schools has begun to emerge, especially at the high school level which shows a ratio of almost 1:1 between public and private high school.

Published on August 18, 2020.

Zafirah Maria Ulfa, Bandung Institute of Technology, Indonesia (corresponding e-mail: zafirah.maria ${ }^{@}$ sbm-itb.ac.id)

Ahmad Danu Prasetyo, Bandung Institute of Technology, Indonesia.

(e-mail: ahmad.danu@sbm-itb.ac.id)
In addition to increasing demand for education, data in 2019 also shows an increase in the duration of undergoing education by $6 \%$ from 2015 . Based on data provided by BPS in Mean Years School or Average Duration of School. This data defined as the number of years used by the population in undergoing formal education, which can be used to determine the quality of education in an area. It shows that every year there's a growth, means that there is an increase in number of people who are undergoing longer formal education period.

\section{A. Statement of Problem}

Stated by International Finance Corporation [5], state education is often considered to have poor quality, has led many parents to look for alternatives to the state sector. This adds another reason for schools to always improve education supporting facilities and infrastructure. Therefore the XYZ Foundation as part of the private education sector needs to carry out its role to continue to improve the quality of its school units and maintain its reputation.

At the time being, the Foundation sees a necessity to encourage the development of one of its units, namely the high school unit. The current high school unit area is still integrated with the junior school unit area. This happen because the junior school unit was built first by the Foundation and later the high school unit. And because of that, the junior school unit occupy most of the area dan already has a better and more comprehensive facilities than the high school. Even though the data in Table 1 shows that there is an increase in the number of students every year, but school can no longer increase the number of new student admissions.

TABLE I: THE NUMBER OF STUDENTS EACH YEAR

\begin{tabular}{ccccc}
\hline \hline $2015 / 2016$ & $2016 / 2017$ & $2017 / 2018$ & $2018 / 2019$ & $2019 / 2020$ \\
\hline 461 & 526 & 597 & 643 & 645 \\
\hline
\end{tabular}

Moreover, continuous curriculum development and the addition of classes and facilities can only be possible if done in a separate area due to land limitations. That's why the foundation planning to construct the new building in a separate area, so that it can freely develop its facilities in the future. With the ongoing curriculum development in high school unit and effort to continue to create innovation, it is hoped that the project will be able to fully support this purpose.

\section{B. Research Objective}

The objective of this study is to find out whether the project of construction new high school building is feasible or not. It is also important to understand the variables of risk that can influence the outcome of the project. 


\section{Research Scope}

With the aim to focus on the study of the project financial feasibility study the scope sets around,

- The investment data which provided by the foundation.

- The financial activity of the high school unit and with financial analysis specific to the high school operational activity.

- Due to the objective of the study is the construction of new high school building, financial data used in the analysis is specific to cover the financial feasibility aspect of the project.

- All data and assumption are acquired from the source inside the foundation through interview and financial report.

\section{RESEARCH MethodolOGY}

To conduct the financial feasibility study and reach a conclusion, this study uses primary data and secondary data. Primary data was obtained from the Foundation in the form of annual financial reports and interview, while secondary data are obtained from books, journals, and articles.

An analysis of internal and external factors related to the scope of the business is also conducted. For both analyses, theories from Hoskisson et al. [3] as business situation analysis will be used. The external analysis section related to the general environment approach and industry environment approach. And for internal analysis section is to find about the resources, capabilities, and core competencies of the company.

The methods explained by Gitman and Zutter [2] are used as investment decision parameters and risk analysis are conducted. This additional analysis will help to give recommendation for the foundation to focus their attention on the possibilities of variables that can change the results of the analysis.

\section{A. Investment Decision Analysis}

Investment decision parameters using theory cited from Gitman and Zutter [2] or commonly known as Financial Feasibility Study will be elaborated below,

\section{Net Present Value}

The Net Present Value (NPV) method discounts the firm's cash flows at the firm's cost of capital. Mean that it is calculated by subtracting a project's initial investment $\left(\mathrm{CF}_{0}\right)$ from the present value of its cash inflows $\left(\mathrm{CF}_{\mathrm{t}}\right)$ discounted by a discount rate. When NPV method is used, both inflows and outflows are measured in terms of present value. The formula is,

$$
N P V=\sum_{t=1}^{n} \frac{C F_{t}}{(1+r)^{t}}-C F_{0}
$$

\section{Internal Rate of Return}

The Internal Rate of Return (IRR) is the discount rate that equates the NPV of an investment opportunity with $\$ 0$ (because the present value of cash inflows equals the initial investment). It is the rate of return that the firm will earn if it invests in the project and receives the given cash inflows.

The formula is,

$$
\sum_{t=1}^{n} \frac{C F_{t}}{(1+I R R)^{t}}=C F_{0}
$$

\section{Payback Period}

Payback Period (PP) is the amount of time required for a company to recover its initial investment in a project as calculated from cash inflows.

\section{Profitability Index}

For a project that has an initial cash outflow followed by cash inflows, the Profitability Index (PI) is simply equal to the present value of cash inflows divided by the initial cash outflow.

The formula is,

$$
P I=\frac{\sum_{t=1}^{n} \frac{C F_{t}}{(1+r)^{t}}}{C F_{0}}
$$

\section{B. Risk Analysis}

\section{Sensitivity Analysis}

This analysis, quoted from Allen at el. [1], leads to the disclosure of the relationship of each of the project's main variables and cash flow. To do this, optimistic and pessimistic estimates are needed for each of the underlying variables. From here the analysis can consider estimates or assumptions that drive cash flow and recalculate NPV on the optimistic and pessimistic values of variables. When conducting a sensitivity analysis of a project or when looking at alternative scenarios, the analysis assesses how serious it is if the realization of a variable is worse than expected.

\section{Scenario Analysis}

Scenario analysis can be used to deal with project risk to capture the variability of cash inflows and NPVs. Cited from Gitman and Zutter [2], scenario analysis is a behavioral approach that uses several possible alternative outcomes (scenarios) to obtain a sense of the variability of returns, measured here by NPV. This technique is often useful in getting a feel for the variability of return in response to changes in a key outcome.

\section{BUSINESS SITUATION ANALYSIS}

Quoting from Hoskisson et al. [3], business situation analysis is defined as a method to analysis the internal and external factors of a business to clearly understand a business's capabilities, customers, potential customers, business environment, and their impact on the company.

\section{A. General Environment Analysis}

The general environment consists of the company's external aspects. Despite having varying impacts, the environmental segment affects all competing companies in the same industry [3].

\section{Politic/Legal Aspect}

Various programs made by the government to realize the awareness of higher education. And some of the programs are direct assistance to students and to their schools in form of financial aid.

\section{Economic Aspect}

It is known that private schools usually have higher education costs, but the costs will be equal to the facilities 
provided. Due to this improvement of economic situation, it is estimated that interested students or prospective high school students will continue to grow.

\section{Sociocultural Aspect}

As a private school that is based on Islamic values, there are certainly many benefits to the school because the majority of the people in the community are also Muslim. The school states that its main advantage is when the community is familiar with the concept of the school.

\section{Technological Aspect}

Given the rapid pace of science and technological development, it is vital for companies to able to fulfil new demands in all aspects of life, including in the education sector. The demand concerns renewal of the education system, such as curriculum renewal. Science and technological development is very important for a school.

\section{Global Aspect}

Bakhtiari [10], globalization is creating opportunities for sharing knowledge, technology, social values, and behavioural norms and promoting developments at different levels including individuals, organizations, communities, and societies across different countries and cultures. Aware of the rapid development of this phenomenon, school establish cooperates with another school in Thailand and Malaysia.

\section{Physical Environment Aspect}

According to Licite and Janmere [7], for several years, various research studies revealed that not only depend on the curriculum, teaching techniques, and social relations, but student achievement also depends on the physical environment of educational institutions.

\section{Demographic Aspect}

Broadly speaking, in The National Long-term Development Plan by Badan Pusat Statistik predicted that Indonesia's population will be 296 million by 2030. And even with the declining of the birth rates productive groups will still dominate the projected proportion of the population of $68 \%$.

\section{B. Industry Environment Analysis}

Compared with the general environment, according to Hoskisson et al. [3], the industry environment has a more direct effect on the company's strategic competitiveness and ability to earn above-average returns.

\section{Threat of New Entrants}

The barriers to entry in this industry is quite high, especially to establish a school. In a sense that's a lot of capital required and legal process to comply with government policy. Expected retaliation also will be high, because existing and bigger institutions can easily give out promotion to attract potential students. That's why the emergence of new high schools is actually relatively low. And it usually takes years to build a reputation that will eventually attract prospective students.

\section{Bargaining Power of Suppliers}

Bargaining power of suppliers is low. XYZ Foundation manages different levels of education usually use the same suppliers, because of that the amount of demand for supplies will be higher and supplier can't risk it. Not to mention that competition between suppliers is very strict, so school have an advantage here.

\section{Bargaining Power of Buyers}

Bargaining power of buyers is low. Having the existence of the same junior high school unit is very advantageous. School can guarantee that nearly $50 \%$ of their junior high school students will continue to enrol here. Because of the convenience offered for enrolment to the high school and the familiar impression that is already attached to the school. In addition, a good reputation easily attracts prospective students and their parents in the community.

\section{Threat of Substitutes}

Threat of substitute is Low. It true that there's an emergence of applied skill training institutions that offer expertise in fulfilling jobs in the industry with shorter time and lower cost. But the goal of the school itself is to produce graduates who can be accepted at leading universities. Therefore students who enrol in general also have a goal to continue to study to university level.

\section{Rivalry Among Existing Firms}

The competitors with another school is moderate. Each school has its own strengths. And the strengths of this school are always tries to prioritize innovations, such as the first full-day school in the city, intensifying schools based on science and technology, and always developing other facilities. And so far the school has always experienced an increase in the number of students.

\section{Internal Analysis}

Continuing in the theory explained by Hoskisson et al. [3] mention that there are components of internal analysis that can lead to competitive advantage and strategic competitiveness.

\section{Resources}

First of all, for tangible resources the financial resources for the foundation comes from the units operational activities. Then for organizational resources, the foundation is committed to make decisions that prioritize its customers, in this case students. The foundation also have strong physical resources which consist of building with comprehensive and up-to-date facilities for each units.

And then for intangible resources having human resources for a school, teachers and staff play an important role in the main goals of the institution. Innovation by being the first full-day school pioneers in the city. The last is reputation, the Foundation has been running for thirty years, and during that time it continues to build the trust of its customers.

\section{Capabilities}

The most striking capabilities of the Foundation are the human resource, management, and marketing capabilities if compared to rivals. In terms of human resource capabilities, the Foundation is able to create commitments between the teachers and students that are in line with the Foundation, and able to carry out its vision and mission to jointly realize the optimal teaching and learning process. Likewise with management capabilities where staff are able to carry out the functions of the Foundation's organization very well so that it raises the values that form the basis of the operations of the units under this Foundation. Finally, marketing capabilities are able to create the reputation of the Foundation and its units so that they can gain and maintain customer loyalty. 


\section{Core Competencies}

Core competencies are the capabilities possessed by the company, which cannot be imitated or difficult to match, because of its unique nature so that it reflects the values adopted and distinguishes it from rivals. The foundation's core competencies lie in the process of operating school units that are in line with their vision and mission as an Islamic private school that has a trusted reputation. School are able to appeal its value as an Islamic school, which is a religion that is embraced by the majority of the population but does not miss on displaying a leading and innovative impression of teaching and learning process.

\section{FinANCIAL FEASIBILITY STUdy}

\section{A. Project Outlook}

This project aims to build new buildings for the high school to increase student capacity. The construction will start with two main buildings, namely the classroom building in April 2020, and the administration office building in October 2020. Both construction is scheduled to be finished in a year, with the completion of administration office in August 2021. Therefore in the school year of 2021 the new buildings are ready to welcome the students. When the construction has been completed, the new classroom building will be able to hold up to 11 more classrooms and both buildings will be able to facilitate 320 more students compared to the existing buildings. The capital expenditure for the project is Rp. 8.231.027.306. The details can be seen in Table 2 below.

TABLE 2: CAPITAL EXPENDITURE

\begin{tabular}{clc}
\hline \hline No. & \multicolumn{1}{c}{ Description } & Value \\
\hline 1 & Classroom Building & 3.776 .107 .893 \\
2 & Administration Office Building & 3.997 .026 .902 \\
3 & Additional Financing & 6.710 .011 \\
4 & School Equipment & 390.555 .000 \\
5 & Office Equipment & 60.627 .500 \\
\hline \hline
\end{tabular}

\section{B. Revenue and Expenses Projection}

The main assumption used to project school revenue in this study is an increase in the sources of income determined by the school. The school has determined that every two years there will be an increase in the sources of income by $5 \%$, so this is used as an assumption for an increase in fees.

Every two years there will be an addition of one class, and so that later it will target 6 science classes and 4 social science classes per year. With each class assumed to have 32 students which was the optimal number of students in the class according to school.

And expense projection is calculated using the assumptions in Table 3. School expenses are divided into several sections as explained on the BNSP (Badan Nasional Standar Pendidikan).

\section{Cash Flow Calculation}

The calculation of financial feasibility is done by using Free Cash Flow and Discounted Cash Flow. At the end of the year projection is added terminal value with the assumption of growth at $6 \%$. And based on the calculation accumulated the value of Rp. 20.184.597.812.

TABLE 3: EXPENSE PROJECTION ASSUMPTION

\begin{tabular}{clc}
\multicolumn{3}{c}{ TABLE 3: EXPENSE PROJECTION ASSUMPTION } \\
\hline \hline No. & \multicolumn{1}{c}{ Expenses } & Assumption \\
\hline 1 & Standar Isi & $2,06 \%$ of Revenue \\
2 & Standar Proses & $4,67 \%$ of Revenue \\
3 & Standar Competensi Lulusan & $8,08 \%$ of Revenue \\
4 & Standar Pendidik dan Tenaga & $3,16 \%$ of Revenue \\
5 & Standar Sarana dan Prasara & $13,77 \%$ of Revenue \\
6 & Standar Pengelolaan & $1,21 \%$ of Revenue \\
7 & Standar Pembiayaan & $39,40 \%$ of Revenue \\
8 & Standar Penilaian & $3,97 \%$ of Revenue \\
9 & Operational Cost & $7,71 \%$ of Revenue \\
\hline \hline
\end{tabular}

\section{Financial Feasibility Result}

Based on the calculation of the various parameters which are used as a reference to assess the project as feasible or not, the results will be elaborated below.

TABLE 4: FINANCIAL FEASIBILITY RESULT

\begin{tabular}{ccc}
\hline \hline Parameters & Value & Threshold \\
\hline NPV & Rp. 8.434 .640 .322 & $>$ Rp. 0 \\
IRR & $18,04 \%$ & $>10 \%$ (Hurdle Rate) \\
PBP & 5,29 years & $<10$ years \\
PI & 2,02 & $>1$ \\
\hline \hline
\end{tabular}

As one of the parameters for assessing project financial feasibility, Net Present Value (NPV) calculations can deliver two possibilities result. The first is that result of the calculation is positive, which can be interpreted that the project is feasible and will generate profit. Conversely if the result of the calculation is negative, then the project is not feasible and will only generate loss. The calculation results for this project NVP is Rp. 8.434.640.322, so it can be said that the project is acceptable.

The second parameter to indicate whether a project is feasible or not is the Internal Rate of Return (IRR). To assess if the project is feasible, the IRR must be greater than the Cost of Capital. If it turns out that the IRR is less than the Cost of Capital, the project is not feasible. IRR resulting from the calculation of this study is $18,04 \%$, which means it is greater than the Hurdle Rate of $10 \%$. Then it can be said that this project is acceptable.

Next, the third parameter is the Payback Period (PBP). The project is considered feasible if the payback period is less than the time period specified to assess the project. For this project the time period for assessing is 10 years. Therefore the calculation of payback period which produces 5,29 years shows that this project is acceptable.

The last is the Profitability Index (PI). The profitability index that deliver a value greater than 1 indicates that the present value of the cash flow generated is greater than the initial investment made. From the calculation results show that the PI obtained by this project is 2,02, it can be concluded that this project is acceptable.

\section{E. Sensitivity Analysis}

Sensitivity analysis is able to help identify which input variables have a strong influence toward the NPV results by changing the assumptions associated with these input variables. By changing the assumptions toward input 
variables about $20 \%$, the results of the analysis are shown in the following Fig. 1. It turns out that only one input variable is sensitive, namely the Realization of New Students.

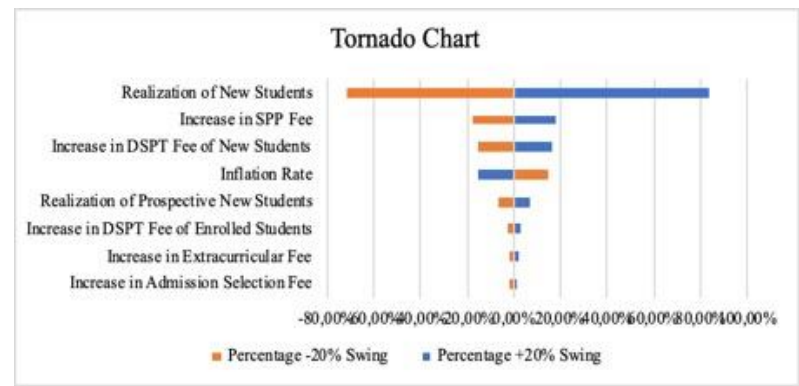

Fig. 1. Sensitivity analysis result.

After analyzing the results of various input variables only one input variable is sensitive, namely the realization of new students. This variable has a significant influence on changes in NPV. Because after testing with changes of $20 \%$ from assumption, the variable show changes up to $83 \%$ toward the NPV result.

\section{F. Sensitivity Analysis}

Scenario analysis is done by changing the realization of new students based on the worst and the best case, and the assumption used for the changes are the minimum and maximum number of students per class. The worst-case is the minimum number of students required for a class based on the school policy, and the best-case is the maximum capacity of student in a classroom. The lowest NPV generated by the worst-case scenario would be Rp. 4.425.784.209, which is still greater than the value for indicating that the project is acceptable

TABLE 5: SCENARIO ANALYSIS

\begin{tabular}{lccc}
\hline \hline \multicolumn{1}{c}{ Variable } & Worst Case & Base Case & Best Case \\
\hline Realization of & 28 & 32 & 36 \\
New Students & & & \\
NPV & $\mathbf{4 . 4 2 5 . 7 8 4 . 2 0 9}$ & $\mathbf{8 . 4 3 4 . 6 4 0 . 3 2 2}$ & $\mathbf{1 2 . 4 4 3 . 4 9 6 . 4 3 4}$ \\
\hline \hline
\end{tabular}

\section{CONCLUSION}

Before conducted the financial feasibility study, an analysis of the business situation is carried out. Based on the business situation, the project is expected to be successful due to the support from both internal and external factors. In analysis of external factors, because Education as one of the crucial needs of the people there is full support from the government and the community itself. For example, support programs from the government and improvement of the economy and demography of the population itself. Not to mention the factors related as a company as a private school with an industrial environment, schools are able to show their superiority when compared to that environment.

Based on the results of the financial feasibility study, it can be concluded that this project is feasible to be implemented. It can be proven from the four parameters used in this study, all of them show acceptable result. The first, can be seen from the NPV that generates value more than 0 which is Rp. 8.434,640.322. Secondly, from the IRR calculation this project resulted in $18,04 \%$ is higher than the cost of capital of $10 \%$. Subsequently for PP, the project can recover its initial investment at 5,29 years from the time period of 10 years specified for assessing the project. The last is the project's PI with 2,02 which is higher than 1 .

Lastly to learn the possible risks that could arise in the future, a risk analysis is conducted. After conducting a risk analysis, it is shown that there are no variables that actually have a significant influence towards the feasibility of the project. Through sensitivity analysis, it can be seen that there is only one variable that significantly influences the NPV calculation results. But that variable does not make the project study result to not feasible, because the lowest NPV generated in the analysis is Rp. 4.425.784.209.

The analysis results state that the project is feasible, hence the school can start construction immediately. But schools must pay attention to the variables that can affect the NPV of the project, namely the realization of new students. Therefore, school must pay attention in determining the quota of their students and must also be able to continue to attract prospective students to fill the quota.

\section{REFERENCES}

[1] Brealy, Richard A., Myers, Stewart A., \& Allen, Franklin, 2017, Principles of Corporate Finance $12^{\text {th }}(E d)$, New York: McGraw-Hill Education.

[2] Gitman, Lawrence J. \& Zutter, Chad J., 2015, Principles of Managerial Finance Global Edition 14 ${ }^{\text {th }}(E d)$, England: Pearson Educational Limited.

[3] Hitt, Michael A., Ireland, R. Duane, \& Hoskisson, Robert E., 2017, Strategic Management: Competitiveness \& Globalization: Concepts and Cases 12 ( $E d)$, Boston: Cengage Learning.

[4] Badan Pusat Statistik, 2013, Proyeksi Penduduk Indonesia 20102035, Jakarta.

[5] International Finance Corporation, 2010, Guide for Investors in Private Education in Emerging Economies, July.

[6] Nowak, A. Z. \& Dahal, Gangadhar, 2016, The Contribution Of Education To Economic Growth: Evidence From Nepal, International Journal of Economic Sciences Vol. V(2).

[7] Licite, Lasma \& Janmere, Lana, 2018, Student Expectations Towards Physical Environment in Higher Education, Engineering for Rural Development, Latvia: Latvia University of Life Sciences and Technologies.

[8] Badan Pusat Statistik, 2020, Rata-Rata Lama Sekolah Menurut Provinsi [Metode Baru], 2010-2019, 18 February. Viewed 3 April, 2020 at https://www.bps.go.id/dynamictable/2020/02/18/1773/ratarata-lama-sekolah-menurut-provinsi-metode-baru-2010-2019.html.

[9] Badan Standar Nasional Pendidikan, Standar Nasional Pendidikan. Viewed 3 June at https://bsnp-indonesia.org/standar-nasionalpendidikan/.

[10] Bakhtiari, Sadegh, 2011, Globalization and Education: Challenges and Opportunities, February. Viewed 21 Mei 2020 at https://www.researchgate.net/publication/242621870_Globalization_ And_Education_Challenges_And_Opportunities. April 6.

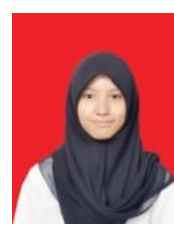

Zafirah Maria Ulfa is a graduate student who earned her undergraduate degree majoring in Graphic Design from Telkom University, Indonesia 2018. She currently pursuing her master degree in Business Administration study program at Bandung Institute of Technology.

Her work experience previously is being an intern in a book publishing company as a graphic designer and in a state institution in the financial and economic advisory division.

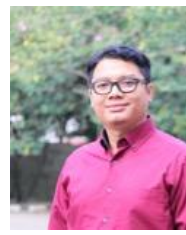

Ahmad Danu Prasetyo is a faculty member at the School of Business and Management, Bandung Institute of Technology (SBM ITB). He obtained a Ph.D degree from the Graduate School of Economics, Keio University, Japan. Danu earned his Bachelor in Industrial Engineering from Telkom Institute of Technology, Indonesia and Master of Science in Management from Bandung Institute of Technology, 
Indonesia. He got a cum laude title for the later degree.

Danu received merit based scholarships for almost in every level of higher studies. Furthermore, he was appointed as Adjunct Researcher during his doctoral study at Keio University. He also had the opportunity to join Asian Development Bank Institute in Tokyo as Research Associate. Danu had also served the Ministry of Finance, Republic of Indonesia as a consultant for various projects, especially in Government Bond Market development. Danu has a wide range of research interest in Economics and Finance, especially in Macroeconomic Policy, Fiscal Policy, Monetary Policy, Public Policy, Stock and Bond Market, and Personal Finance. Some of his papers were published in Scopus indexed journals such as International Journal of Economic Policy in Emerging Economies, Journal of Comparative Asian Development and Global Business and Economic Review. 